\title{
Writing Literacy Based on the Game Toward Children in Minangkabau
}

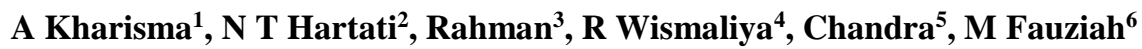 \\ $\left\{{ }^{1}\right.$ annisakharismaupi@upi.edu, ${ }^{2}$ tatat@upi.edu, ${ }^{3}$ rahmanprofupi@upi.edu, ${ }^{4}$ risawismaliya@upi.edu, \\ ${ }^{5}$ chandra@fip.unp.ac.id, ${ }^{6}$ kfauziah19@upi.edu \} \\ 1,2,3,4 Universitas Pendidikan Indonesia Bandung, Indonesia \\ ${ }^{5}$ Universitas Negeri Padang, Indonesia \\ ${ }^{6}$ STKIP Syekh Manshur Pandeglang, Indonesia
}

\begin{abstract}
Writing literacy was one of the earliest known literacies in the history of human civilization. Writing literacy is classified as functional and great useful literacy in daily life, especially for low-grade students. The obstacle, the habit of writing in low class becomes a boring thing because the activities are carried out monotonously without any variation in learning. Moreover, in an increasingly modern era, lower class students are more preoccupied with technology, and it is feared that students will not be literate and do not recognize Minangkabau children's games, one of which is the finger game. Therefore, the main objective of this research was to improve writing skills based on Minangkabau children's games, namely by playing the finger. The results showed the emergence of the view that the game of finger as one of the cultures of Minangkabau children who were able to deliver early writing learning to realize writing literacy in the digital era. Early writing learning based on finger games was able to bring students into a pleasant writing habit.
\end{abstract}

Keywords: Writing Literacy; Finger Game; Minangkabau

\section{INTRODUCTION}

Writing skills by language teaching experts are placed at the highest level in the language acquisition process. This is because writing skills are productive skills that can only be obtained after listening, speaking and reading skills. This also causes writing skills to be the most difficult language skills [1], [2]. Although writing skills are difficult, their role in human life is very important throughout the ages. Writing activities can be found in human activities every day, such as writing letters, reports, books, articles, and so on. It can be said, that human life is almost inseparable from writing activities [3], [4]. Writing is vital in all aspects of learning and life. Without writing skills, students cannot work efficiently and achieve success, both in class and in real life outside the classroom. Therefore, writing skills must be trained to start from elementary school, so students are able to express thoughts, feelings, and information in writing [5], [6].

Writing skills are far more meaningful if you pay attention to writing literacy in its application. Writing literacy is categorized into three text forms that are most often found by students in school and in daily life, namely: (1) narrative prose, text in which the author tells 
a story, whether fact or fiction; (2) expository prose, text in which the author describes, explains, or conveys factual information or opinions; and (3) documents, displaying information such as diagrams, maps, tables, graphs, lists, or instruction sets [7], [8]. The tendency of elementary students to know prose texts and be able to write them. It will be far more meaningful if the writing made by students is in the form of prose that comes from daily life or based on his experience [9], [10].

Literacy is developed through the specific study of English in all its forms, allowing students to understand how English works in different social contexts and critically assessing the opinions, facts, and intentions of the author, and helping them to make increasingly sophisticated language choices in the texts they write them yourself [11], [12]. Literacy is defined to affect classroom instruction, community service, and literacy opportunities offered to students and adults with broad support needs [13], [14]. The definition of literacy must explain the nature of concepts that are appropriate to certain conditions, contextual, have clear, relative, and culturally bound consequences. Literacy is far more than "an individual's ability to process written information in everyday life" as is generally defined [15]. Literacy is above all social characteristics, culture is sensitive, and always embedded in certain situations and contexts [16], [17].

Based on observations with respondents through observation and interviews found several problems. First, the teaching material used does not adequately describe the effective writing literacy learning process, so students have not been able to harmonize relations between ideas, and have not been able to harmonize interfaith relations. As a result, the ideas conveyed are difficult to understand. Some of the sentences compiled by students have not been effective because there are still many redundant words. In addition, the sentences compiled by students appear to be incomplete in accordance with the correct structure, namely subject, predicate, an object. Some sentences that are arranged do not have a subject, and others do not have a predicate. Second, writing literacy teaching materials used in elementary schools still, lack students to recognize attitudes that need to be built in the prose that is made. The attitude that students write is not even derived from their experience in applying that attitude. Third, teaching materials used by students are difficult to make the beginning of an interesting story, determine the ending, and work on conflict and climax. In addition, many spelling errors and punctuation were found. Writing learning problems are caused by several factors, one of which is the limited knowledge of the teacher about writing and the limited time the teacher fosters writing learning.

Based on the problems that have been raised, development research needs to be done. One solution that can be done to improve literacy in writing student prose in producing innovation and developing character intelligence in elementary school towards the generation of gold is to conduct research on the development of literacy teaching writing materials for first-grade elementary school students.

The guided writing strategy is one of the writing learning strategies that language teachers can apply [18], [19]. This strategy was developed by Blake and Spenneto which stated: guided writing is a strategy for developing writing skills and using writing skills to improve learning. This strategy can be used at almost all levels. This strategy is an instructional framework for all forms of selected writing tasks [20], [21].

The guided writing strategy can be developed using play learning methods. The method of play that is suitable for elementary students is a game that is close to the lives of students. Games that are close to student life, namely local wisdom-based games. Games based on local wisdom are one of them is the maramal finger game which tends to train students in writing. 
Finger march performance is assumed to increase literacy in writing low-grade elementary school students.

\section{RESEARCH METHOD}

The research method conducted refers to the Mixed Method development model with Model Plomp. Plomp model consists of three stages, namely: (1) preliminary research, (2) prototyping phase, and (3) assessment stage [22]. Plomp model used can determine the needs of students at the preliminary analysis stage and produce a prototype design with self-evaluation and expert review evaluations by experts at the prototyping phase based on needs. The prototype was tested using the one to one evaluation method. The results of the evaluation were continued with trials with the small group method and field test to find out the practicalities. Whereas to find out the effectiveness of testing using the field test evaluation method at the stage of stage assessment in different classes.

\section{RESULTS AND DISCUSSION}

The results of developing teaching materials for writing skills using the method of finger fortune-telling can be described as follows:

The definition phase is carried out an analysis on several aspects, which include: curriculum analysis, needs analysis, and analysis of the characteristics of students.

The phase prototyping phase is the second stage of the plomp model. At this stage is a continuation of the preliminary research phase. In the phase prototyping stage, the designing of writing materials using the maramal finger game method in elementary school I. The teaching materials are tailored to the Core Competencies and Basic Competencies curriculum designated, then arranged according to the steps of the game maramal finger game finger. The designed material encourages learners to be skilled in writing. The materials are complemented by colorful drawings for learners. Thus, this material will be appreciated by the learners and can support the learning process.

The format of the preparation of teaching materials is modified from the structure of teaching materials according to the Ministry of National Education which consists of (1) cover, (2) introduction, (3) table of contents, (4) usage instructions, (5) Core Competencies and Basic Competencies to be achieved, (6) title, (7) objectives to be achieved, (8) tasks or activities, (9) supporting information, (10) reflection, and (11) bibliography. The phase of prototyping phase aims to produce writing material using a finger maramal method that is valid, practical and effective so that it is suitable for use in the learning process. This development phase consists of three stages, namely: design validation, practicality test, and effectiveness test. The results of the study can be described as follows:

An evaluation of the validation instrument is conducted to get a valid data collection instrument. The data collection instrument was validated by 3 experts. After the instrument is said to be valid and the teaching material is validated by expert validators and practitioners. Furthermore, after the teaching materials are designed, the teaching material is validated by 6 expert validators, and 3 practitioners are validators to assess aspects of content, language, presentation, and graphics. The conclusion of the results of the overall teaching material analysis is the teaching material of writing skills using the method of finger maramal in the first class of $\mathrm{SD}$ is valid. The results of validation and writing teaching materials using the maramal finger method have a valid category. Validation results can be seen in the following table: 
Table 1. Teaching Material Feasibility Test

\begin{tabular}{lcc}
\hline \multicolumn{1}{c}{ Aspect } & Average & Category \\
Validation & & \\
a. Results of instrument validation & $89,25 \%$ & Very Worthy \\
b. Results of the validation of teaching materials & $88,47 \%$ & Very Worthy \\
& & \\
\hline
\end{tabular}

A trial was conducted to see the practicality of the teaching material after the validation process with the experts was completed. Tests for teaching materials for writing skills using the finger maramal method were performed at Kampung Olo Padang Elementary School 04 Padang. The practicality of the teaching materials developed can be seen from the observation sheet of the implementation of learning, the results of practical analysis by teachers and students, and the observation of the use of teaching materials by students. Practical results can be seen in the following table:

Table 2. Teaching Material Practicality adn Effectiveness Test

\begin{tabular}{|c|c|c|}
\hline Aspect & Average & Category \\
\hline \multicolumn{3}{|l|}{ Practicality } \\
\hline a. Results of the assessment of Teacher's response & $89,47 \%$ & Very practical \\
\hline b. Results of the assessment of student responses & $93 \%$ & Very practical \\
\hline c. Results of Observation on the Use of Teaching Materials & $94,25 \%$ & Very practical \\
\hline \multicolumn{3}{|l|}{ Effectiveness } \\
\hline a. Student activities & $89,3 \%$ & Very good \\
\hline b. Assessment of the writing process & $82,93 \%$ & Very good \\
\hline c. Results Evaluation writing & $85 \%$ & Very good \\
\hline \multicolumn{3}{|l|}{ Spread } \\
\hline a. Student activities & $91,56 \%$ & Very good \\
\hline b. Assessment of the writing process & $85,95 \%$ & Very good \\
\hline c. Assessment of results & $88,33 \%$ & Very good \\
\hline
\end{tabular}

The deployment stage is the stage of using teaching materials in a broader scope. This spread can be done in other classes, other schools, or other teachers. In this study, the distribution was carried out on a limited scale, namely class I SDN 16 Air Tawar Padang. The aim is to test the effectiveness of using these teaching materials on different objects, situations, and conditions.

Teaching materials that have been developed are said to be valid if they meet certain criteria. The characteristics of the product are said to be valid if it reflects the soul of knowledge (state of the art knowledge) [22], [23]. This was what is said by content validation. Furthermore, the product components must be consistent with each other (construct validity). Therefore, the validation of the writing material using the method of finger maramal play emphasizes the content and construct. In this study, the validation is further broken down into product validation carried out on content, language, presentation, and graphics [24], [25].

Validation in this study was conducted by six expert validators and 3 practitioners validators. Product validation can be done by several experts or experienced experts to assess new products designed so that further weaknesses and advantages can be identified. The validation results from the experts were collected and then analyzed to find the average of each indicator and each aspect.

Based on the results of data validation of teaching materials by expert validators and practitioner validators, the percentage was $88.35 \%$. If seen from the predetermined categories, 
the teaching materials that have been developed are categorized as very valid. Therefore, it can be concluded that the teaching materials developed are in accordance with the demands of the curriculum. Material presentation was in accordance with the indicators formulated and in accordance with the development of students [26], [27].

The contents of teaching materials are also in accordance with the writing learning material in the first grade of elementary school. Various concepts and elaboration of the tasks contained in teaching materials make it easier for students to develop ideas contained in their thoughts into written forms. The contents of teaching materials have been able to achieve the selected basic competencies [27], [28]. In addition, the use of language in teaching materials uses simple and easy to understand sentences by students. Sentences use communicative language so that students are easily understood [29], [30]. Then, the teaching materials developed were designed with attractive colors, namely the dominant colors of blue and green so that they could motivate students to follow the learning process well. Thus it can be concluded that the teaching materials developed have been declared valid and can be used in the learning process. This is because the teaching materials have met the indicators that have been determined after being validated by the expert validator and the practitioner validator then the revision process is carried out until the teaching material can reach the valid criteria that have been set [31]-[33].

The practicality of teaching materials relates to the ease of use of the devices used by teachers and students. Its practice or practicality means that it is easy to implement, easy to check, and equipped with clear instructions that make it easier for teachers and students to use the learning devices used [34], [35]. To see whether the teaching materials developed were practical or not, a trial was conducted on first-grade students of Public Elementary School 04 Kampung Olo, Padang City. Seeing the Lesson Plan that has been developed before, the learning process is conducted one meeting with a time allocation of 4x35 minutes. Practices observed were the level of implementation of lesson plans, teacher response questionnaires, student response questionnaires, and interviews with the practicalities of learning devices.

Teaching material can be said to be effective if it has an effect or a good influence on the achievement of learning objectives. The effectiveness of the learning program was characterized by the following characteristics: (a) successfully delivering students to achieve predetermined instructional goals, (b) providing an attractive learning experience, actively involving students so that support the achievement of instructional goals, (c) have the facilities that support the learning process [36], [37]. Based on the results of the effectiveness test at the development stage, the average results of the writing skills assessment showed a high percentage.

At this 1 st meeting, at the meeting, 1 student was very enthusiastic about working on teaching materials because this was something new so that they followed each process very well. Active students ask and express opinions about their experiences according to the theme [37], [38]. Learners do step-step writing well. However, there are some students who have sketched the essay very well, but when writing it is actually very deviated from the framework of his essay. However, the results of the essay he made were very good even though it did not fit the essay, so these students succeeded in terms of the assessment of results but failed in terms of the writing process.

In learning 2, students have sufficiently understood the steps to write the finger maramal method and done it very enthusiastically especially with the holiday theme. Students have many ideas for writing so that they have an impact on the process and results of writing students who are increasing.

Learning 3 was the level of enthusiasm of students has decreased. This is because they look rather bored to keep writing. But after being given motivation and explanation the students do 
each step well. Although there are some students who are lazily working on it and with more supervision the students continue to work on the teaching material.

The level of effectiveness of teaching materials is also strengthened by data at the deployment stage. At this stage of dissemination, the learning process situation feels somewhat different because students in this deployment stage are easier to understand what is conveyed by the teacher. The students are all enthusiastic, actively asking questions, giving opinions and working on each step in the teaching material [39], [40]. Therefore, the average writing result of students at the distribution stage is higher than the trial phase. At this stage of deployment, there are no significant difficulties, only there are some students who are rather slow to understand writing. But after several times students understand and are able to work on teaching materials very well.

Based on the above explanation, it can be concluded that writing teaching materials using the finger maramal method have effective criteria. This is because students have used writing processes as a whole and systematically. Then, after writing exercises and assessments, the learning achievement of students also tends to increase [41]. Both in terms of learning activities, assessment of the writing process, and evaluation of writing results. Therefore, it can be concluded writing materials use the effective finger maramal method for grade I elementary school.

\section{CONCLUSIONS}

The level of validity of narrative writing teaching materials using the maramal finger method has very valid criteria. This is in accordance with the results of validation from expert validators and education practitioner validators. These results illustrate that the teaching material developed has been valid and can be used in the learning process.

The practicality of teaching materials for writing narratives uses the method of playing maramal finger has very practical criteria. The practicality of teaching materials for writing narratives using the method of finger maramal play in Grade I of Elementary School as a whole in a very practical category. This is obtained from the results of observations of the implementation of the lesson plan on teachers who teach, teacher responses, student responses, and observation sheets for the use of teaching materials. These results illustrate that teaching materials are very practical and can assist in carrying out the process of learning to write narratives in grade I of elementary school.

The level of effectiveness of narrative writing teaching materials using the finger maramal method has effective criteria. The effectiveness of teaching narrative writing materials using the method of finger maramal play in grade I elementary school can be known through student activities, process evaluation, and assessment of the results of writing narratives of students. The results of observations of student activities, assessment of processes, and assessment of the results of writing narratives of students provide a very good picture, meaning that the use of teaching materials in learning to write narratives has been effectively implemented.

The results showed the emergence of the view that the game of maramal finger as one of the cultures of Minangkabau children who were able to deliver early writing learning in realizing literacy writing in the digital era. Beginning writing learning based on maramal finger games is able to bring students into a pleasant writing habit. 


\section{REFERENCES}

[1] F. Cahyaningrum, Andayani, and K. Saddhono, "Improving Argumentation Writing Skill Through Think Pair Share Model Using Audiovisual Media For Students X-10 G," J. Pendidik. dan Kebud., vol. 3, no. 1, pp. 44-55, 2018.

[2] I. Elgort, "Blog posts and traditional assignments by first- and second-language writers," Lang. Learn. Technol., vol. 21, no. 2, pp. 52-72, 2017.

[3] A. Mumpuni and L. Nurpratiwiningsih, "The Development Of A Web-Based Learning To Improveof A Creative Writing Abilityof Pgsd Students," 2017.

[4] P. Bulut, "The effect of primary school students' writing attitudes and writing selfefficacy beliefs on their summary writing achievement," Int. Electron. J. Elem. Educ., vol. 10, no. 2, pp. 281-285, 2017.

[5] M. Habibi and Chandra, "Strategi Direct Writing Activity Sebagai Upaya Peningkatan Keterampilan Menulis Deskripsi Bagi Siswa Kelas Ii Sd," J. Inov. Pendidik. dan Pembelajaran Sekol. Dasar, vol. 2, no. 1, 2018.

[6] S. Han and J.-A. Shin, "Teaching Google search techniques in an L2 academic writing context," Lang. Learn. Technol., vol. 21, no. 3, pp. 172-194, 2017.

[7] S. Yim and M. Warschauer, "Web-Based Collaborative Writing in L2 Contexts: Methodological Insights From Text Mining,” Lang. Learn. Technol., vol. 21, no. 211, pp. 146-165, 2017.

[8] S. E. Sulak, "Investigation of writing habits of primary school teachers," Int. Electron. J. Elem. Educ., vol. 10, no. 4, pp. 497-504, 2018.

[9] S. Han, "Teaching Google search techniques in an L2 academic writing context," Lang. Learn. Technol., vol. 21, no. 3, pp. 172-194, 2017.

[10] M. Mirzaee and B. Yaqubi, "A conversation analysis of the function of silence in writing conferences," Iran. J. Lang. Teach. Res., vol. 4, no. 2, pp. 69-86, 2016.

[11] Taufina and Chandra, "DEVELOPING THE BIG QUESTIONS AND BOOKMARK ORGANIZERS ( BQBO ) STRATEGY - BASED LITERACY READING LEARNING MATERIALS IN THE 4 TH GRADE OF ELEMENTARY SCHOOL," Int. Conf. Sci. Educ. Teach., vol. 118, no. 5, pp. 857-864, 2017.

[12] M. Botelho de Magalhães, S. Cotterall, and D. Mideros, "Identity, voice and agency in two EAL doctoral writing contexts," J. Second Lang. Writ., vol. 43, no. August 2017, pp. 4-14, 2019.

[13] Muhammadi, Taufina, and Chandra, "LITERASI MEMBACA UNTUK MEMANTAPKAN NILAI SOSIAL SISWA SD,” LITERA, vol. 17, no. 2, pp. 202-212, 2018.

[14] J. Morton and N. Storch, "Developing an authorial voice in $\mathrm{PhD}$ multilingual student writing: The reader's perspective," J. Second Lang. Writ., vol. 43, no. August 2017, pp. 15-23, 2019.

[15] Chandra, Mayarnimar, and M. Habibi, "Keterampilan Membaca dan Menulis Permulaan Menggunakan Model VARK untuk Siswa Sekolah Dasar," J. Inov. Pendidik. dan Pembelajaran Sekol. Dasar, vol. 2, no. 1, pp. 72-80, 2018.

[16] Mayarnimar and Taufina, "Validity Analysis of the Vark ( Visual , Auditory , ReadWrite , and Kinesthetic ) Model - Based Basic Reading and Writing Instructional Materials for the 1St Grade," Int. Conf. Sci. Educ. Teach., vol. 118, pp. 870-874, 2017.

[17] M. Michel, J. Kormos, T. Brunfaut, and M. Ratajczak, "The role of working memory in young second language learners' written performances," J. Second Lang. Writ., vol. 45, no. May 2018, pp. 31-45, 2019. 
[18] S. A. Gibson, "Guided Writing Lessons: Second-Grade Students' Development of Strategic Behavior," Read. Horizons, vol. 48, no. 2, pp. 111-132, 2008.

[19] K. L. Wright, T. S. Hodges, and E. M. McTigue, "A validation program for the SelfBeliefs, Writing-Beliefs, and Attitude Survey: A measure of adolescents' motivation toward writing," Assess. Writ., vol. 39, no. April 2018, pp. 64-78, 2019.

[20] Y. F. Lan, C. L. Hung, and H. J. Hsu, 'Effects of guided writing strategies on students' writing attitudes based on media richness theory," Turkish Online J. Educ. Technol., vol. 10, no. 4, pp. 148-164, 2011.

[21] A. Sturm, "Observing writing processes of struggling adult writers with collaborative writing," J. Writ. Res., vol. 8, no. 2, pp. 301-344, 2016.

[22] Plomp and Nieveen, An Introduction to Educational Design Research. 2013.

[23] E. G. Allan and D. L. Driscoll, "The three-fold benefit of reflective writing: Improving program assessment, student learning, and faculty professional development," Assess. Writ., vol. 21, pp. 37-55, 2014.

[24] S. Dym, "wards a Model of Poet try Wri ting De evelop ment as a a Soci ally Co ontextu ualised Proces ss," J. Theory Pract. Educ., no. 9, 2017.

[25] A. Becker, "Student-generated scoring rubrics: Examining their formative value for improving ESL students' writing performance,” Assess. Writ., vol. 29, pp. 15-24, 2016.

[26] T. Brunfaut, L. Harding, and A. O. Batty, "Going online: The effect of mode of delivery on performances and perceptions on an English L2 writing test suite," Assess. Writ., vol. 36, no. December 2017, pp. 3-18, 2018.

[27] C. Kuiper, J. Smit, L. de Wachter, and J. Elen, "Scaffolding tertiary students' writing in a genre-based writing intervention," J. Writ. Res., vol. 9, no. 1, pp. 27-59, 2017.

[28] D. Crusan, L. Plakans, and A. Gebril, "Writing assessment literacy: Surveying second language teachers' knowledge, beliefs, and practices," Assess. Writ., vol. 28, pp. 43-56, 2016.

[29] D. V. Bommarito, "Collaborative research writing as mentoring in a U.S. english doctoral program,” J. Writ. Res., vol. 8, no. 2, pp. 267-299, 2016.

[30] E. Niyibizi, E. Sibomana, and J. Perumal, "Learning to teach writing through a distance education programme: Experiences of Rwandan secondary school English teachers," Read. Writ., vol. 10, no. 1, pp. 1-10, 2019.

[31] S. L. Songxaba and L. Sincuba, "The effect of social media on English second language essay writing with special reference to WhatsApp," Read. Writ., vol. 10, no. 1, pp. 1-7, 2019.

[32] L. M. Drennan, "Traversing the spaces of higher education through writing," Read. Writ., vol. 8, no. 1, pp. 1-8, 2017.

[33] B. T. Ramoroka, "The use of interactional metadiscourse features to present a textual voice: A case study of undergraduate writing in two departments at the University of Botswana," Read. Writ., vol. 8, no. 1, pp. 1-11, 2017.

[34] N. Mather and P. Rule, "Getting the boys involved: Using an interactive questionnaire to investigate Grade 6 boys' writing," Read. Writ., vol. 8, no. 1, pp. 1-10, 2017.

[35] E. Esambe, C. Mosito, and S. Pather, "First-year students' essay writing practices: Formative feedback and interim literacies," Read. Writ., vol. 7, no. 1, pp. 1-11, 2016.

[36] C. Akinyeye and P. Plüddemann, "The story of a narrative: Teaching and assessing English writing in a township school," Read. Writ., vol. 7, no. 1, pp. 1-8, 2016.

[37] L. Olivier and J. Olivier, "Exploring writing apprehension amongst Afrikaans-speaking first-year students," Read. Writ., vol. 7, no. 1, pp. 1-10, 2016.

[38] F. Liu and P. Stapleton, "Connecting writing assessment with critical thinking: An 
exploratory study of alternative rhetorical functions and objects of enquiry in writing prompts," Assess. Writ., vol. 38, no. November 2017, pp. 10-20, 2018.

[39] T. S. Hodges, K. L. Wright, S. A. Wind, S. D. Matthews, W. K. Zimmer, and E. McTigue, "Developing and examining validity evidence for the Writing Rubric to Inform Teacher Educators (WRITE)," Assess. Writ., vol. 40, no. March, pp. 1-13, 2019.

[40] I. Cuevas et al., "Collaborative writing of argumentative syntheses from multiple sources: The role of writing beliefs and strategies in addressing controversy," J. Writ. Res., vol. 8, no. 2, pp. 205-226, 2016.

[41] L.E. Rahmawati, S. Suwandi, K. Saddhono, B. Setiawan. 2019. "Need analysis on the development of writing competency test for foreign university students," Humanities and Social Sciences Reviews vol. 7 no. , pp. 467-471. 2019 